UDC 576.31

\title{
Ultrastructural organization of replicating chromatin in prematurely condensed chromosomes
}

\author{
E. A. Arifulin
}

A. N. Belozersky Institute of Physico-Chemical Biology,

M. V. Lomonosov Moscow State University,

Leninskie gory, house 1, building 40, Moscow, Russian Federation, 119992

lewanit@yandex.ru

\begin{abstract}
Aim. The ultrastructural aspect of replicating chromatin organization is a matter of dispute. Here, we have analyzed the ultrastructural organization of replication foci using prematurely condensed chromosomes (PCC). Methods. To investigate the ultrastructure of replicating chromatin, we have used correlative light and electron microscopy as well as immunogold staining. Results. Replication in PCC occurs in the gaps between condensed chromatin domains. Using correlative light and electron microscopy, we observed that the replication foci contain decondensed chromatin as well as 80 and $130 \mathrm{~nm}$ globules, those were also found in condensed non-replicating chromatin domains. Using immunogolding, we demonstrated that DNA replication in S-phase PCC occurs in loose chromatin on the periphery of dense chromatin domains. Conclusion. Replication in PCC occurred in the decondensed chromatin neighboring the condensed chromatin without formation of special structures.
\end{abstract}

Keyword s: chromatin, replication, prematurely condensed chromosomes (PCC), ultrastructure.

\section{Introduction}

A characteristic feature of DNA replication in nuclei of higher eukaryotes is that it occurs at a few hundred discrete replication foci [1]. The molecular functioning and composition of replication foci have been previously comprehensively studied [2]. However, their ultrastructural organization was a matter of dispute for a long time, and it has remained unclear until now. In various studies, the replication foci were examined using chromatin digestion followed by chromatin electroelution, which visualized them as ovoid bodies, so called «the replication factories» ranging from 100 to $1000 \mathrm{~nm}$ in diameter, that contain all the necessary replication factors to drive the progression of many replication forks [3, 4]. However, the removal of $90 \%$ of chromatin, which was required to discover those bodies, violently alters the native chromatin structure. Later studies revealed that the structures analogous to the replication factories could be visualized in permeabilized cells without chromatin extraction [5]. Two types of DNA replicating factories, approximately 100 - and 400-nm in diameter, were observed. Both of them contained the proteins involved in DNA replication (polymerase $\alpha$ and PCNA). These data were obtained using permeabilization, which could be a source of artifacts [6]. In contrast to the previously described data, the studies on unpermeabilized cells indicate that DNA replication occurs in a loose material on the periphery of condensed chromatin domains [7-9]. Thus, the data concerning the replication domain structure are contradictory. The existence of special bodies, which implement DNA replication, has been only confirmed in permeabilized cells.

It is possible that the structures such as replication factories could be masked in situ by an intra-nuclear material, e.g., RNA and proteins. Physiological con-

\footnotetext{
(C) 2015 E. A. Arifulin; Published by the Institute of Molecular Biology and Genetics, NAS of Ukraine on behalf of Biopolymers and Cell. This is an Open Access article distributed under the terms of the Creative Commons Attribution License (http://creativecommons.org/licenses/by/4.0/), which permits unrestricted reuse, distribution, and reproduction in any medium, provided the original work is properly cited
} 
densation of interphase chromatin with partial removal of the soluble fraction can be achieved in prematurely condensed chromosomes (PCC). Formation of PCC can be induced by fusing mitotic and interphase cells [10]. It has been demonstrated that chromatin condensation does not invade replication foci during S-phase PCC [11-13]. Therefore, this experimental system provides a great opportunity to investigate replicating chromatin in situ. In this study, we propose the application of a method utilizing PCC and a 5-ethynyl-2'-deoxyuridine (EdU) replication detection system as an approach for studying the ultrastructure of replication fo ci.

\section{Material and Methods}

M-HeLa cells were grown in DMEM supplemented with L-glutamine, $10 \%$ fetal calf serum (HyClone, UK) and an antibiotic/antimycotic solution (Invitrogen, USA). Before experimentation, cells were seeded on glass coverslips or in Petri dishes and grown for 1-2 days until they formed a subconfluent monolayer. To induce the formation of PCC, cells were washed twice with PBS, incubated in $50 \%$ PEG (Sigma, USA) in PBS for $30 \mathrm{sec}$ and washed three more times with PBS. Subsequently, the cells were returned to culture medium and incubated for an hour. Replication pulse labeling was performed by the addition of $20 \mu \mathrm{M}$ EdU during the last 5 (for immunogolding) or 10 (for light microscopy) min of incubation.

After PCC induction, the cells were prepared for the chromosome spread by harvesting from Petri dishes using a Trypsin-EDTA solution and incubation in $0.075 \mathrm{M} \mathrm{KCl}$ for $10 \mathrm{~min}$ at $37^{\circ} \mathrm{C}$. Cell suspensions were subsequently fixed by overnight incubation in a chilled ethanol-acetic acid solution. Fixed cell suspensions were dropped onto wet glass pieces and air-dried at room temperature. After drying, the samples were rehydrated and incubated in $1 \%$ BSA for $30 \mathrm{~min}$. EdU-labeled cells were developed using an Alexa Fluor-555 Imaging Kit (Invitrogen, USA). The samples were additionally stained with $1 \mu \mathrm{g} / \mathrm{ml}$ DAPI (Sigma, USA) and mounted into Mowiol 4-88 with the addition of $50 \mathrm{mg} / \mathrm{ml}$ DABCO.

For correlative electron and light microscopy, cells were lysed in $1 \%$ Triton X-100 for $1 \mathrm{~min}$ and then fi- xed in $2.5 \%$ glutaraldehyde (both solutions contained $2 \mathrm{mM}$ Tris- $\mathrm{HCl}$ and $3 \mathrm{mM} \mathrm{CaCl}$ ). After extensive washing and $30 \mathrm{~min}$ incubation in a $1 \% \mathrm{BSA}$ solution, EdU was developed according to the ClickiT® EdU Alexa Fluor 555 Imaging Kit (Invitrogen, USA) protocol. The samples were embedded into Epon 812 (Sigma, USA) using a standard protocol for electron microscopy excluding osmium tetroxide, as it suppresses fluorescence. Ultrathin sections were stained with DAPI and photographed using a fluorescent microscope. Stacks of optical sections were deconvoluted with a constrained iterative algorithm using the AxioVision 3.1 software (Carl Zeiss, Germany). Subsequently, the sections were examined with electron microscope.

For immunoelectron microscopy, the cells were lysed in $1 \%$ Triton X-100 for $1 \mathrm{~min}$ and fixed in $3.7 \%$ formaldehyde (both solutions contained $50 \mathrm{mM}$ PIPES and $5 \mathrm{mM} \mathrm{MgCl}$ ). This was followed by $30 \mathrm{~min}$ incubation with a $1 \%$ BSA solution in PBS with 5 $\mathrm{mM} \mathrm{MgCl}$ and EdU developing. During the immunostaining procedure, the cells were incubated for 1 hour with anti-Alexa Fluor 488 antibodies (Invitrogen, USA) diluted 1:1000 in PBS with $5 \mathrm{mM} \mathrm{MgCl}_{2}$. After extensive washing, the cells were incubated for 1 hour with Nanogold antibodies (Nanoprobes, USA) conjugated to $1.2 \mathrm{~nm}$ gold particles, diluted 1:50 in PBS with $5 \mathrm{mM} \mathrm{MgCl}$. After extensive washing, the samples were additionally fixed with $2.5 \%$ glutaraldehyde in PBS with $5 \mathrm{mM} \mathrm{MgCl}$ and treated with $1 \mathrm{mg} / \mathrm{ml}$ sodium borohydride. Subsequently, the cells were subjected to the silver enhancement procedure [14] followed by the standard electron microscopy embedding protocol. To obtain images, we used JEM-1400 electron microscope (Jeol, Japan) and Axiovert 200M (Carl Zeiss, Germany) equipped with ORCAII-ERG2 camera (Hamamatsu, Japan) for fluorescent microscopy.

\section{Results and Discussion}

To detect replicating chromatin in PCC, EdU was added to the culture medium for $10 \mathrm{~min}$, and the cells were subsequently harvested and fixed for the chromosome spread preparation. Fig. 1, A shows a general view of cells with PCC. The presence of replica- 

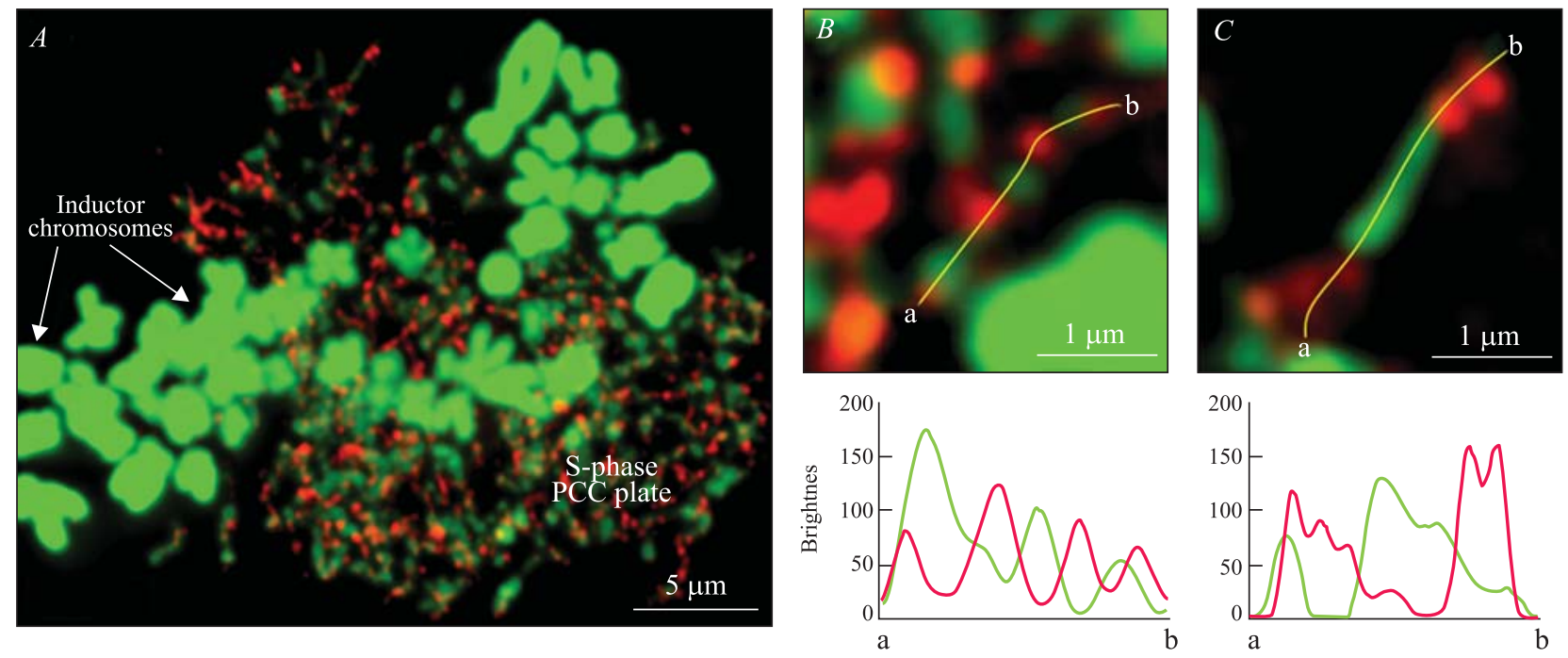

Fig. 1. Chromosome spread of S-phase PCC. DNA is colored in green, and the EdU label is in red. Graphs on the bottom show the relative brightness in both channels along the profile line (yellow) of the corresponding pictures. A - A general view of PCC plates with mitotic chromosomes; $B$-A chromatin fiber with short alternating condensed and replicating domains; $C$ - A chromatin fiber with long condensed and coupled replication foci

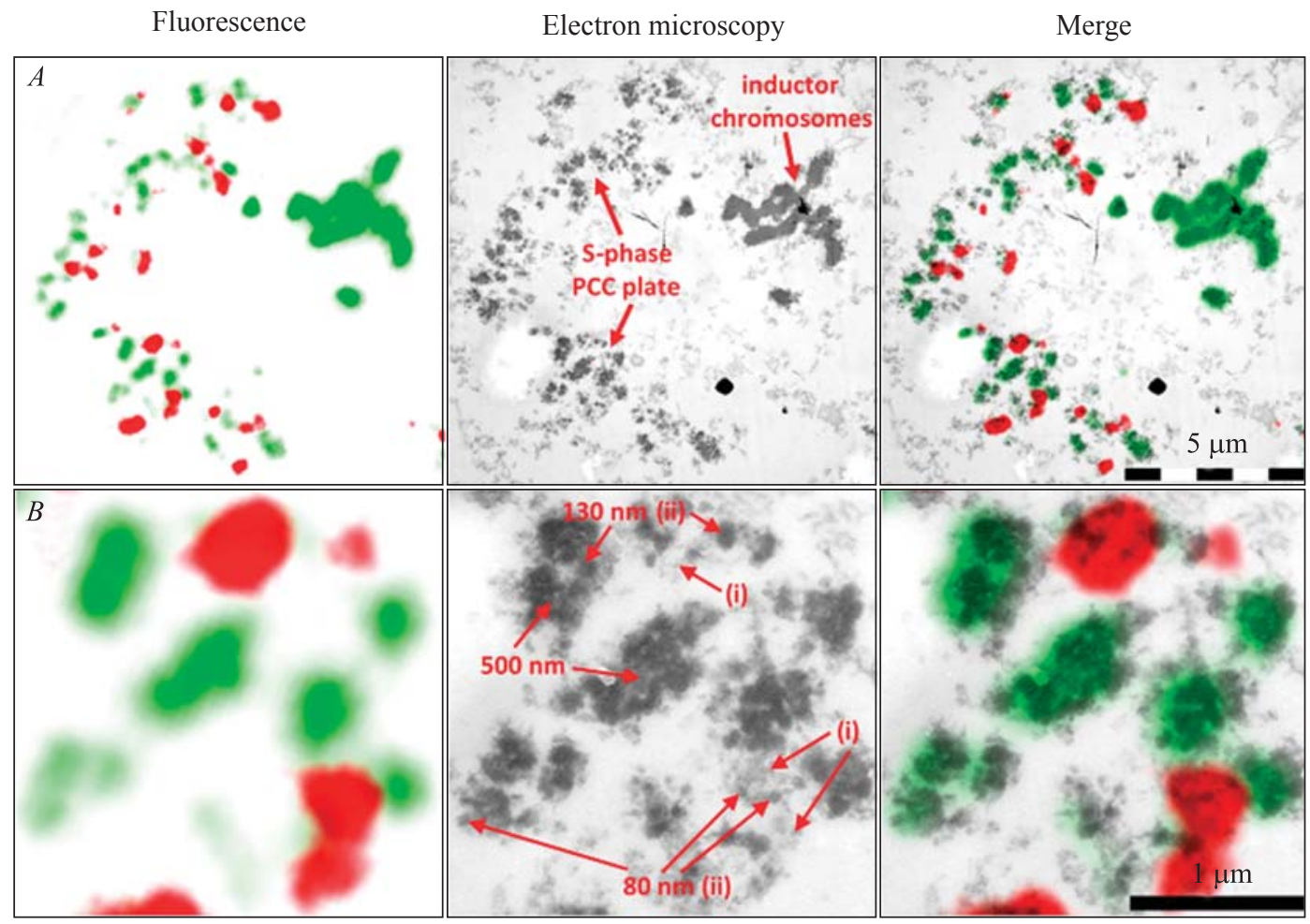

Fig. 2. Correlative microscopy of S-phase PCCs. Cells were permeabilized and fixed in $2 \mathrm{mM}$ Tris- $\mathrm{HCl}_{\mathrm{with}} 3 \mathrm{mM} \mathrm{CaCl}$. $\mathrm{DNA}$ is colored in green, and the EdU label is in red. A - A general view of S-phase PCC and mitotic chromosomes at the ultrastructural level; $B-500$-nm chromatin complexes (green on merge) and replication zones (red on merge) with decondensed chromatin (i) and 80 and $130 \mathrm{~nm}$ globules (ii) 
tion labeling indicated S-phase PCC. The relatively large inductor mitotic chromosomes displayed an organization that was typical for the spread samples. PCC consisted of chromatin globules and fibers of different thickness. There was no colocalization between condensed chromatin domains and replication foci. We analyzed linear fragments of S-phase PCC. Replicating foci are typically separated by the beads of condensed chromatin (Fig. 1, B), but some of them could be adjoined like beads on a string, not separated by the condensed chromatin. Importantly, there were many relatively long fragments of the condensed S-phase chromosomes, but the replicating regions were always divided into discrete repli-

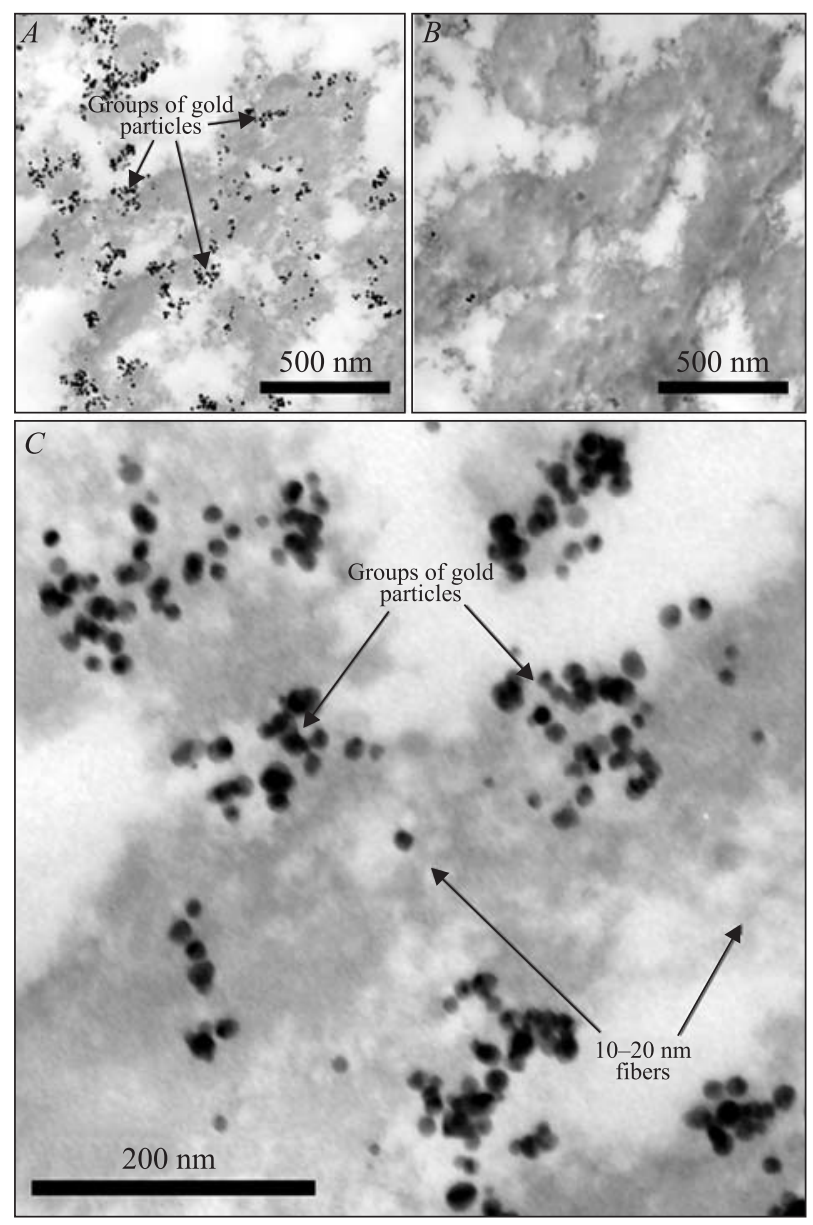

Fig. 3. Immunogolding of S-phase PCC. A - PCCs with groups of silver granules; $B$ - Mitotic chromosomes nearly completely lack silver particles; $\mathrm{C}$ - Silver granules on the periphery of condensed chromatin blocks cation foci (Fig. 1, C). In all cases, the brightness profile demonstrated almost no colocalization between the condensed chromatin and replication foci (Fig. 1, B, C graphs). Similar 'beads on a string' distribution of replication foci was reported in the cells with drug-induced PCC [15]. Our results are also in agreement with the early studies of DNA replication on PCC model [11-13].

The internal organization of replication foci cannot be revealed using light microscopy. To analyze the ultrastructural organization of replication foci, we used correlative light and electron microscopy. This approach allowed us to combine the cell images, which were subsequently photographed using fluorescent and electron microscopes (Fig. 2, A). At the ultrastructural level, S-phase PCC consisted of condensed chromatin complexes with average diameters of approximately $500 \mathrm{~nm}$, which was half the thickness of inductor's mitotic chromosomes from the same section. The $500 \mathrm{~nm}$ complexes consisted of 80 and $130 \mathrm{~nm}$ globules that were often joined to fibers (Fig. 2, B). Similar globules (so-called chromosomeres) were described in partially decondensed metaphase chromosomes [16]. There was no replication label in the $500 \mathrm{~nm}$ chromatin agglomerates as in the inductor cell chromosomes (Fig. 2, B). EdUlabeled regions contained two types of structures (Fig. 2, B): (i) decondesed chromatin, which occupied most of the replication foci area and (ii) loosely lying globules of 80 and $130 \mathrm{~nm}$, similar to those found in condensed chromatin. Thus, the replicating chromatin regions were less densely packed compared to the non-replicating chromatin complexes. However, the correlative microscopy did not allow us to determine whether replication occurs in the decondensed chromatin or in the globules.

We used pre-embedded immunogold labeling to investigate the replication foci more accurately. Because EdU labeling is adapted for fluorescent detection only, we applied antibodies versus fluorochromes to reveal EdU nucleotide [17]. The PCC were strongly labeled with silver granules (Fig. 3, A), whereas almost no labeling was observed inside the inductor metaphase chromosomes (Fig. 3, B). The labeled regions (ultrastructural equivalents of repli- 
cation foci) had irregular form and were preferentially localized on the periphery or between the condensed chromatin blocks (Fig. 3, C). Scant groups of gold particles were also visible inside the condensed chromatin but were typically found in small zones of decondenced material. The label inside the condensed chromatin was never detected.

It appears that, like in interphase nucleus $[8,9]$, PCC chromatin replicates in a decondensed state. We were unable to visualize any special structures that could be interpreted as «replication factories». There were, however, loosely packed 80 and $130 \mathrm{~nm}$ globules inside replication foci, but the globules of the same size and morphology were visualized inside the condensed (non-replicating) chromatin. It could thus be supposed that the structures such as the «replication factories» may only appear in the interphase cells in conditions of in vivo permeabilization, during which the nucleoplasm material aggregates with chromatin.

\section{Conclusions}

The DNA replication in S-phase PCC occurs in the decondensed chromatin. The replication foci at an ultrastructural level have an irregular form, and contain no special structures that could be interpreted as the «replication factories».

\section{Funding}

This work was supported by the Russian Science Foundation (project 14-15-00199).

\section{REFERENCES}

1. Nakamura H, Morita T, Sato C. Structural organizations of replicon domains during DNA synthetic phase in the mammalian nucleus. Exp Cell Res. 1986;165(2):291-7.

2. Natsume T, Tanaka TU. Spatial regulation and organization of DNA replication within the nucleus. Chromosome Res. 2010;18(1):7-17.

3. Hozák P, Hassan AB, Jackson DA, Cook PR. Visualization of replication factories attached to nucleoskeleton. Cell. 1993; 73(2):361-73.

4. Hozák P, Jackson DA, Cook PR. Replication factories and nuclear bodies: the ultrastructural characterization of replication sites during the cell cycle. J Cell Sci. 1994;107 (Pt 8): 2191-202.
5. Philimonenko AA, Hodný Z, Jackson DA, Hozák P. The microarchitecture of DNA replication domains. Histochem Cell Biol. 2006;125(1-2):103-17.

6. Jaunin F, Fakan S. DNA replication and nuclear architecture. J Cell Biochem. 2002;85(1):1-9. Review.

7. Liu DF, el-Alfy $M$, Leblond CP. DNA changes involved in the formation of metaphase chromosomes, as observed in mouse duodenal crypt cells stained by osmium-ammine. II. Tracing nascent DNA by bromodeoxyuridine into structures arising during the S phase. Anat Rec. 1995;242(4):449-61.

8. Jaunin F, Visser AE, Cmarko D, Aten JA, Fakan S. A new immunocytochemical technique for ultrastructural analysis of DNA replication in proliferating cells after application of two halogenated deoxyuridines. J Histochem Cytochem. 1998; 46(10):1203-9.

9. Jaunin F, Visser AE, Cmarko D, Aten JA, Fakan S. Fine structural in situ analysis of nascent DNA movement following DNA replication. Exp Cell Res. 2000;260(2):313-23.

10. Johnson RT, Rao $P N$. Mammalian cell fusion: induction of premature chromosome condensation in interphase nuclei. Nature. 1970;226(5247):717-22.

11. Hanks SK, Rao PN. Initiation of DNA synthesis in the prematurely condensed chromosomes of G1 cells. J Cell Biol. 1980;87(1):285-91.

12. Hanks SK, Gollin SM, Rao PN, Wray W, Hittelman WN. Cell cycle-specific changes in the ultrastructural organization of prematurely condensed chromosomes. Chromosoma. 1983; 88(5):333-42.

13. Hameister H, Sperling K. Description of a chromosome replication unit in individual prematurely condensed human S-phase chromosomes. Chromosoma. 1984;90(5):389-93.

14. Danscher G. Localization of gold in biological tissue. A photochemical method for light and electronmicroscopy. Histochemistry. 1981;71(1):81-8.

15. Gotoh E. Visualizing the dynamics of chromosome structure formation coupled with DNA replication. Chromosoma. 2007;116(5):453-62.

16. Zatsepina OV, Polyakov VY, Chentsov YS. Chromonema and chromomere. Chromosoma. 1983;88(2):91-7.

17. Zhironkina OA, Kurchashova SY, Brattseva AL, Cherepaninets VD, Strelkova OS, Belmont AS, Kireev II. Overcoming steric hindrances during replication of peripheral heterochromatin. Cell Tissue Biol. 2015;9(2):110-8

\section{Ультраструктурна організація \\ хроматину, що реплікується в передчасно конденсованих хромосомах}

\section{Є. А. Арифулін}

Мета. До цих пір немає єдиної думки про ультраструктурі реплицирующихся хроматину. Ми проаналізували ультраструктурну організацію Реплікаційний фокуса в клітках 3 передчасно конденсованими хромосомами (ПКХ). Методи. Для вивчення хроматину на ультраструктурному рівні ви- 
користовували методи кореляційної електронної та світлової мікроскопії, а також іммуноголдінг. Результати. Було показано, що реплікація в ПКХ відбувається в проміжках між доменами конденсованого хроматину. С допомогою кореляційної мікроскопії було встановлено, що в Реплікаційний фокусах присутній деконденсірованний хроматин і глобули діаметром 80 і 130 нм, так само присутні в конденсованих нерепліцірующіхся хроматінових доменах. Більш того, за допомогою іммуноголдінга було показано, що реплікація ДНК в S-фазних ПКХ відбувається в пухкому хроматині на периферії щільних хроматінових доменів. Висновки. Реплікація в ПКХ відбувається в деконденсірованном хроматині сусідить 3 конденсованим хроматином без утворення спеціальних структур.

К л юч о в і с л о в а: хроматин, реплікація, передчасно конденсовані хромосоми (ПКХ), ультраструктура.

\section{Ультраструктурная организация реплицирующегося хроматина в преждевременно конденсированных хромосомах}

\section{Е. А. Арифулин}

Цель. До сих пор нет единого мнения об ультраструктуре реплицирующегося хроматина. Мы проанализировали уль- траструктурную организацию репликационного фокуса в клетках с преждевременно конденсированными хромосомами (ПКХ). Методы. Для изучения хроматина на ультраструктурном уровне использовали методы корреляционной электронной и световой микроскопии, а также иммуноголдинг. Результаты. Было показано, что репликация в ПКХ происходит в промежутках между доменами конденсированного хроматина. С помощью корреляционной микроскопии было установлено, что в репликационных фокусах присутствует деконденсированный хроматин и глобулы диаметром 80 и 130 нм, так же присутствующие в конденсированных нереплицирующихся хроматиновых доменах. Более того, с помощью иммуноголдинга было показано, что репликация ДНК в S-фазных ПКХ происходит в рыхлом хроматине на периферии плотных хроматиновых доменов. Выводы. Репликация в ПКХ происходит в деконденсированном хроматине соседствующем с конденсированным хроматином без образования специальных структур.

Кл юч е в ы е с л о в а: хроматин, репликация, преждевременно конденсированные хромосомы (ПКХ), ультраструктура.

Received 01.07.2015 